\title{
Treatment of Hidradenitis Suppurativa with Infliximab
}

\author{
Tratamento de hidradenite supurativa com infliximab
}

Tiago Torres $^{1}$

It was with interest that we read the recent article published by Obadia et al reporting the unsuccessful treatment of a case of hidradenitis suppurativa with infliximab. ${ }^{1}$ Indeed, we had used infliximab for treating two patients suffering from severe hidradenitis suppurativa, with many years of evolution, that had been previously treated with systemic antibiotics, isotretinoin and finasteride without results. Both patients presented an extensive dermatosis, active, with grat impact on their quality of life. The treatment with infliximab was carried out with doses of $5 \mathrm{mg} / \mathrm{kg}$ in the $0,2,6$ weeks and subsequently at every 8 weeks without presenting reactions to infusion. In both cases it was not observed any improvement with the treatment reason why it was decide to stop it, after 7 months, due to a clear absence of answer

\author{
Manuela Selores ${ }^{2}$
}

Various sporadic cases have been published as well as some small series of cases suggesting that therapeutics with infliximab could be effective to treat hidradenitis suppurativa. ${ }^{2,3}$ As Obadia et al reported, the therapeutic success is much more attractive to publishers than reports of unsuccessful cases. But, if new treatments are disclosed the effectiveness of some therapeutics can be overestimated creating important obliquity. The fact that we have not managed to publish the two mentioned clinical cases yet confirms this idea. It is necessary to have more controlled studies and with a larger number of patients in similar situations to this one. Apart from being an incentive to the publication of therapeuthic failures it would also be a way of diminishing the obliquity associated with the multiple publications of sporadic cases.

\footnotetext{
Work carried out in the Dermatological Service of the "Santo Antonio" Hospital - Porto, Portugal. Financial Support: None. Conflict of Interests: None

Doctor of the Dermatology Service of the "Santo Antonio" Hospital - Porto, Portugal.

Professor of Dermatology of the Faculty of Biomedical Medicine of the University of Porto, Portugal. - Director of the Dermatological Service of the "Santo Antonio" Hospital - Porto, Portugal.
}

\section{REFERÊNCIAS}

1. Obadia DL, Daxbacher ELR, Jeunon T, Gripp AC. Hidradenite supurativa tratada com infliximabe. An Bras Dermatol. 2009;84:695-7.

2. Adams DR, Gordon KB, Devenyi AG, Ioffreda MD. Severe hidradenitis suppurativa treated with infliximab infusion. Arch Dermatol. 2003;139:1540-3.

3. Fardet L, Dupuy A, Kerob D, Levy A, Allez M, Begon E, et al. Infliximab for severe hidradenitis suppurativa:transient clinical efficacy in 7 consecutive patients. J Am Acad Dermatol. 2007;56:624-8.
ENDEREÇO PARA CORRESPONDÊNCIA / MAILING ADDRESS: Tiago Torres

Rua D. Manuel II $s / n$, ex-Cicap, Serviço de Dermatologia, 4100

Porto, Portugal.

e-mail: tiagotorres2002@botmail.com

How to cite this article/Como citar este artigo: Torres T, Selores M. Treatment of hidradenitis suppurativa withinfliximab. An Bras Dermatol. 2010;85(4):576. 